\title{
Characterizing the Phytotoxic Effects of Hydrogen Peroxide Root Dips on Hybrid Phalaenopsis Orchid Plants
}

\author{
Renata Goossen ${ }^{1}$ and Kimberly A. Williams ${ }^{1}$
}

AdDITIONAL INDEX wORDs. home remedy, moth orchid, orchids, Phalaenopsis, root disease, root rot

SuMMARY. Hydrogen peroxide $\left(\mathrm{H}_{2} \mathrm{O}_{2}\right)$ is a well-known oxidizing agent often used as a remedy by consumers to treat algae and root decay from presumed root disease on interior plants, as well as to encourage root growth and health. To characterize the phytotoxic effects and define the safe concentration threshold for $\mathrm{H}_{2} \mathrm{O}_{2}$ use on 'Vivaldi' hybrid phalaenopsis orchid (hybrid Phalaenopsis), root systems were dipped for 3 minutes in $0 \%, 3 \%, 6 \%$, or $12 \% \mathrm{H}_{2} \mathrm{O}_{2}$ one time and observed in greenhouse conditions for the following 27 days. Root systems of each plant were assessed over time for percent visible root damage; ratings of root health on a scale of 1 to 5 points, with 5 points indicating "very healthy"; and final fresh and dry weights. To determine when symptoms manifested above the root zone, foliage and flower damage was evaluated over time by assessing percent visible foliage damage, ratings of foliage health, percent foliar wilt, flower/bud count, and final foliage and flower fresh and dry weights. Over the evaluation period, the root health rating of the 'Vivaldi' hybrid phalaenopsis orchids treated with $12 \% \mathrm{H}_{2} \mathrm{O}_{2}$ decreased from 5 to 1.13 , whereas those treated with $3 \% \mathrm{H}_{2} \mathrm{O}_{2}$ only decreased from 5 to $4.13 . \mathrm{H}_{2} \mathrm{O}_{2}$ concentrations of $6 \%$ and $12 \%$ damaged root health permanently, whereas the $3 \%$ $\mathrm{H}_{2} \mathrm{O}_{2}$ concentration only caused minor damage to overall root health. However, algae were not killed at the 3\% rate. Neither foliage nor flowers were seriously affected during the 3 weeks after application, but foliage wilt did result in the $6 \%$ and $12 \%$ treatments by week 4 . As $\mathrm{H}_{2} \mathrm{O}_{2}$ concentration increased, fresh weights decreased in roots and leaves. Although a single $3 \% \mathrm{H}_{2} \mathrm{O}_{2}$ root dip did not result in severe symptoms of phytotoxicity, the treatment's long-term plant health effects are unknown. Because the $3 \% \mathrm{H}_{2} \mathrm{O}_{2}$ root dip caused minor plant health setbacks and failed to subdue algae populations in the root zone, consumers should be wary of using $\mathrm{H}_{2} \mathrm{O}_{2}$ to improve orchid (Orchidaceae) root health and should instead focus on altering care and watering practices.

$\mathrm{H}$ ome remedies for pest and disease problems experienced by plant consumers abound on blogs, forums, and social media groups. However, neither the threshold for phytotoxicity nor efficacy of most of these treatments has been subjected to evaluation under replicated or controlled conditions.

$\mathrm{H}_{2} \mathrm{O}_{2}$ is a well-known oxidizing agent often used as a remedy by consumers to treat algae and root decay from presumed root disease on interior plants, as well as to encourage root growth and health. Specifically, $\mathrm{H}_{2} \mathrm{O}_{2}$ is used by many consumers and orchid (Orchidaceae) enthusiasts as a treatment for root decay, presumed to be caused by root rot pathogens, in orchids (e.g., Bottom, 2017; Miss Orchid Girl, 2014). In agricultural production systems, $\mathrm{H}_{2} \mathrm{O}_{2}$ is used successfully as a treatment to control plant pathogens in irrigation water (Raudales et al., 2014).
Baldry (1983) discussed the antimicrobial properties of $\mathrm{H}_{2} \mathrm{O}_{2}$, which act effectively as both a bactericide and a sporicide. Ali (2018) reported that seed treatment and soil drenching with $0.25 \%$ to $2 \% \mathrm{H}_{2} \mathrm{O}_{2}$ in greenhouse conditions suppressed root rot pathogens Fusarium solani, Pythium, Rhizoctonia, and other disease organisms, and improved plant survival of thyme (Thymus vulgaris). Webber et al. (2009) concluded that anecdotal reports of
$\mathrm{H}_{2} \mathrm{O}_{2}$ in irrigation solutions resulting in growth stimulus may be a result of decreasing or eliminating diseases in substrate rather than serving as a direct stimulus to the plant.

However, like most home remedies, using $\mathrm{H}_{2} \mathrm{O}_{2}$ on orchid roots has not been investigated in a controlled study to determine safety or efficacy of use. As a reactive oxygen species (ROS), $\mathrm{H}_{2} \mathrm{O}_{2}$ can harm cell nuclei, proteins, and lipids of living cells when dosed too high (Krumova and Cosa, 2016). Phytotoxicity from $\mathrm{H}_{2} \mathrm{O}_{2}$ has rarely been quantified and characterized on horticultural crops. Webber et al. (2009) reported that soil application of $0.05 \%$ to $0.1 \%$ $\mathrm{H}_{2} \mathrm{O}_{2}$ decreased nasturtium (Tropaeolum majus) foliage dry weight and flower number. Eicher-Sodo et al. (2019) characterized its phytotoxic effects on common microgreens and lettuce (Lactuca sativa) cultivars. Although applied to foliage rather than roots, they found that the same concentration of $\mathrm{H}_{2} \mathrm{O}_{2}$ caused unique responses in each cultivar tested, suggesting a broad range of phytotoxicity effects even within the same type of plant (Eicher-Sodo et al., 2019).

Because phalaenopsis orchids (Phalaenopsis hybrids) are epiphytic, their roots have a unique absorptive complex of velamen and exodermis that, compared with the roots of other plant species, takes in moisture and mineral nutrients passively, and protects from dehydration and physical damage (Bercu et al., 2011). As such, their epiphytic roots are managed differently than those of other interior plant species. Notably, consumers can easily overwater epiphytic orchids, which leads to root decay (Bottom, 2012).

The objective of this trial was to determine the rate at which $\mathrm{H}_{2} \mathrm{O}_{2}$ causes symptoms of phytotoxicity in phalaenopsis orchids, and the highest rate that can be used safely by con-

\begin{tabular}{llll}
\hline $\begin{array}{l}\text { Units } \\
\text { To convert U.S. to SI, } \\
\text { multiply by }\end{array}$ & U.S. unit & SI unit & $\begin{array}{l}\text { To convert SI to U.S., } \\
\text { multiply by }\end{array}$ \\
\hline 29.5735 & $\mathrm{fl} \mathrm{oz}$ & $\mathrm{mL}$ & 0.0338 \\
2.54 & inch $(\mathrm{es})$ & $\mathrm{cm}$ & 0.3937 \\
28.3495 & $\mathrm{oz}$ & $\mathrm{g}$ & 0.0353 \\
1 & $\mathrm{ppm}$ & $\mathrm{mg} \cdot \mathrm{kg}^{-1}$ & 1 \\
1 & $\mathrm{ppm}$ & $\mathrm{mg} \cdot \mathrm{L}^{-1}$ & 1 \\
1 & $\mathrm{ppm}$ & $\mu \mathrm{L} \cdot \mathrm{L}^{-1}$ & 1 \\
$\left({ }^{\circ} \mathrm{F}-32\right) \div 1.8$ & ${ }^{\circ} \mathrm{F}$ & ${ }^{\circ} \mathrm{C}$ & $\left({ }^{\circ} \mathrm{C} \times 1.8\right)+32$
\end{tabular}


sumers. The focus of this study was on the development of phytotoxicity and not on treatment efficacy. However, we also evaluated the secondary effects related to plant longevity and algae reduction in the root zone after $\mathrm{H}_{2} \mathrm{O}_{2}$ treatment.

\section{Materials and methods}

Plant material and environment. Mature, standard-type hybrid 'Vivaldi' hybrid phalaenopsis orchid plants (Green Circle Growers, Oberlin, OH) were shipped on 25 Jan. 2021 and arrived in Manhattan, KS, on 29 Jan. Plants with at least eight fully open flowers were acclimated for 3 weeks before the experiment began on 23 Feb. in a glass-glazed greenhouse. Day and night temperature set points were $20^{\circ} \mathrm{C}$. Temperature and relative humidity were logged every $15 \mathrm{~min}$ [HOBO Temperature and RH Logger MX2301A; Onset Computer Corp., Bourne, MA (Fig. 1)]. Plants were set under $52 \%$ white knit shadecloth (PAK Unlimited, Cornelia, GA) that was doubled on $10 \mathrm{~d}$ after treatment (DAT) to reduce light intensity further. Plants were left in their original growing containers and substrate: clear plastic 5 -inch $(700-\mathrm{mL})$ pots (Modiform, Leusden, The Netherlands) with bottom drainage and pine bark substrate. Plants were fertilized once on arrival with $\approx 100 \mathrm{ppm}$ nitrogen from $20 \mathrm{~N}-4.3 \mathrm{P}-16.5 \mathrm{~K}$ (Compass Minerals, Overland Park, KS) and irrigated overhead as needed.

Received for publication 28 July 2021. Accepted for publication 4 Oct. 2021

Published online 19 November 2021.

${ }^{1}$ Department of Horticulture and Natural Resources, Kansas State University, 1712 Claflin Road, 2021 Throckmorton Plant Sciences Center, Manhattan, KS 66506-5506

We thank Green Circle Growers for donating the plant material used in this research, Jacob Hueste for assisting with greenhouse space preparations, and Judy O'Mara and Tim Todd, Kansas State University's Department of Plant Pathology, for assisting with microscopy and reviewing the manuscript. This manuscript has been assigned Contribution no. 21-326-J from the Kansas Agricultural Experiment Station (KAES). This project was supported by KAES. Its contents are solely the responsibility of the authors and do not necessarily represent the official views of the KAES. From an undergraduate research project by Renata Goossen.

K.A.W. is a Professor and University Distinguished Teaching Scholar.

K.A.W. is the corresponding author. E-mail: kwilliam@ksu.edu.

This is an open access article distributed under the CC BY-NC-ND license (https://creativecommons. org/licenses/by-nc-nd/4.0/).

https://doi.org/10.21273/HORTTECH04923-21
Because root systems were out of the container during data collection 1 to 10 DAT, the plants required daily irrigation. Throughout the remainder of the experiment (11-27 DAT), orchids were irrigated less frequently, about every 2 to $3 \mathrm{~d}$.

EXPERIMENTAL SETUP. Four $\mathrm{H}_{2} \mathrm{O}_{2}$ rates of 0 ppm, 30,000 ppm (3\%), 60,000 ppm (6\%), and 120,000 ppm (12\%) were applied as a single subirrigation dip of the root system, imitating consumer methods. According to at least 12 online orchid blogs, discussion forums, and YouTube (San Bruno, CA) channels, $3 \% \mathrm{H}_{2} \mathrm{O}_{2}$ is the most common recommended rate for treating presumed root rot and cleaning orchid roots of other pests and pathogens before repotting (e.g., Miss Orchid Girl, 2014; My First Orchid, 2016; Orchid Friends, 2020). Rates less than $3 \%$ were also trialed preexperiment to determine whether phytotoxic symptoms appeared. To delineate the phytotoxic effects clearly resulting from $\mathrm{H}_{2} \mathrm{O}_{2}, 3 \%$ was the lowest rate of $\mathrm{H}_{2} \mathrm{O}_{2}$ used. Twelve percent food-grade $\mathrm{H}_{2} \mathrm{O}_{2}$ (Blubonic, Santa Monica, CA) was diluted with distilled water to create $3 \%$ and $6 \%$ concentrations. Because $\mathrm{H}_{2} \mathrm{O}_{2}$ degrades over time, especially after the bottle seal is broken, the solution was used immediately after opening. To mimic consumer practice, the decorative ceramic containers in which the plants were originally packaged were used to accomplish the root dip. Each orchid in its plastic pot was lowered into 500 $\mathrm{mL}$ of the appropriate $\mathrm{H}_{2} \mathrm{O}_{2}$ solution for $3 \mathrm{~min}$. A visible bubbling reaction could be seen at the surface of the root zone, ensuring that the $\mathrm{H}_{2} \mathrm{O}_{2}$ was reactive. Plants were not irrigated the following day. Each of the four treatments were replicated four times, resulting in 16 plants. Plants were arranged on a greenhouse bench in a completely randomized design.

Data collected. Two types of data were collected: root system assessment and foliage/flower assessment. Root systems were evaluated on $0,1,2,3,4,5,6,7$, and 10 DAT. Roots were assessed by removing each plant from its container, then rating and photographing them. To avoid desiccation of root zones during this process, plants were irrigated immediately after data collection. Percent visible damage and root health ratings were recorded using a 5-point root health rating scale (Table 1 ). Concurrently, observations of moisture uptake capability and root initial presence were noted. On 7 DAT, root cross sections were observed under a compound microscope (Olympus, Center Valley, PA) to evaluate the effects of the $\mathrm{H}_{2} \mathrm{O}_{2}$ treatments across rates.

Both foliage and flower data were collected to determine when symptoms manifested above the root zone. Percent visible damage, percent foliage wilt, flower/bud counts, and foliage health ratings were collected on $0,1,2$, $3,4,5,6,7,10,14,16,20$, and 27 DAT. To assess overall foliage health change over time, a 5-point foliage health rating scale was developed (Table 2 ). Percent foliar wilt was calculated by dividing the number of leaves displaying wilt symptoms by the total leaf count of each plant. These data provided documentation of the change in total foliage turgidity over time (Fig. 2). Flowers and buds were counted on each date to determine abscission over time.

On 27 DAT, the root system, foliage, and inflorescence with peduncle of each plant were separated. The fresh weight of each group of plant tissue was measured. Tissues were dried at $70{ }^{\circ} \mathrm{C}$, after which dry weight was measured.

Statistical analyses. Analysis of variance was conducted by date on each data type. Means were separated using Tukey's honest significant difference test at a $95 \%$ confidence interval. Statistical software (JMP Pro version 15.1.0; SAS Institute, Cary, NC) was used.

\section{Results}

Root Damage. Although similar phytotoxic symptoms in the root zone resulted from the use of $\mathrm{H}_{2} \mathrm{O}_{2}$ across treatments, the timeline of symptom development and degree of damage varied with $\mathrm{H}_{2} \mathrm{O}_{2}$ concentration. As $\mathrm{H}_{2} \mathrm{O}_{2}$ concentration increased, symptoms manifested to a greater degree and at a faster rate (Fig. 3). Phytotoxic symptoms appeared in the root zone sequentially and progressed from wrinkled, dehydrated roots (Fig. 4A), to salt excretion on root surfaces (Fig. 4B), to algae death (Fig. 4C), and eventually to root decay (Fig. 4D). Root decay was characterized by orange, brown, and black discoloration 

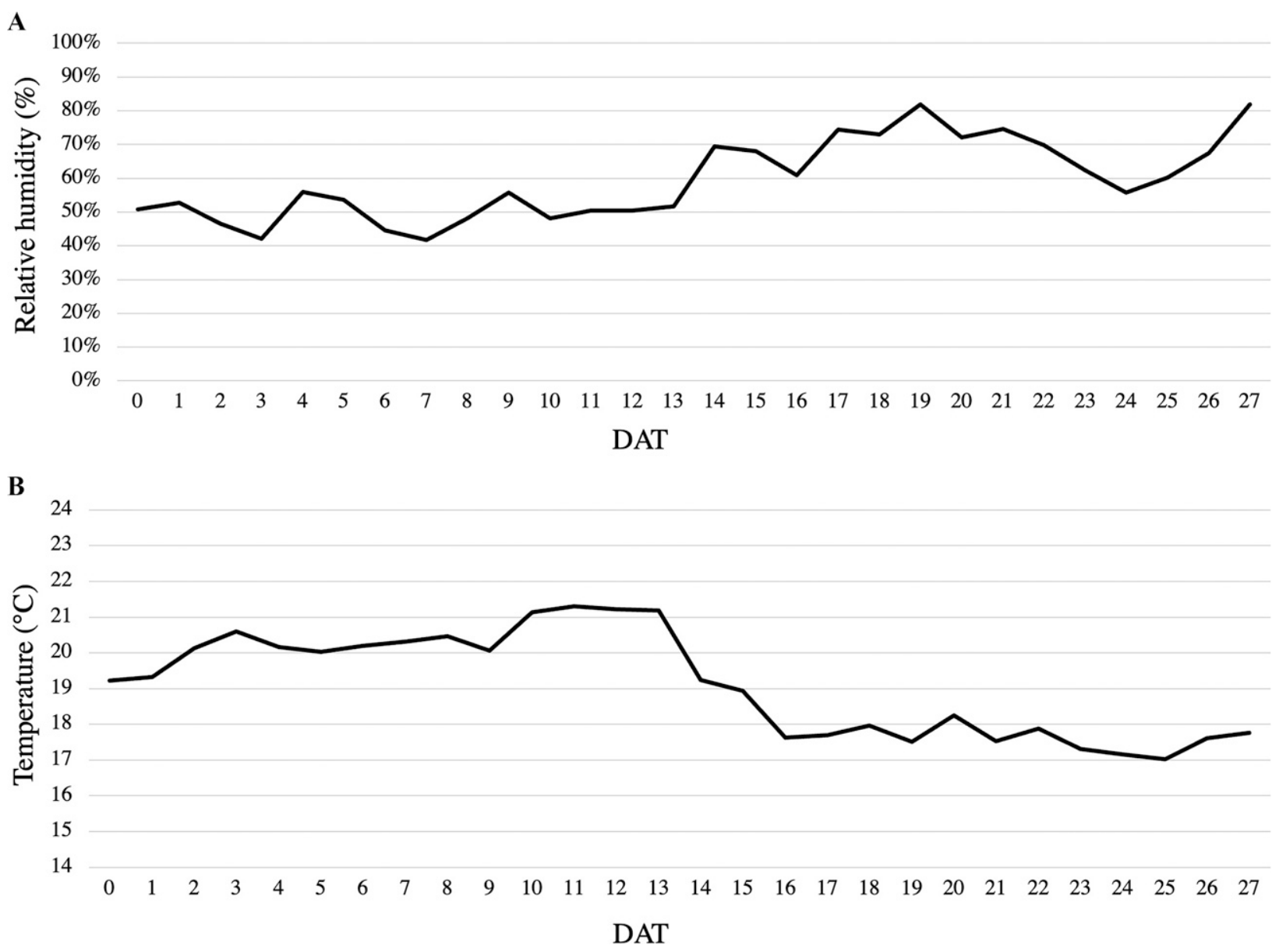

Fig. 1. Greenhouse (A) relative humidity and (B) temperature were recorded every $15 \mathrm{~min}$ from 1 to $27 \mathrm{~d}$ after treatment (DAT) of orchids with hydrogen peroxide. Temperature set point was $20{ }^{\circ} \mathrm{C}$ day and night. $\left(1.8 \times{ }^{\circ} \mathrm{C}\right)+32={ }^{\circ} \mathrm{F}$.

on the outside of the roots and a soft, mushy texture.

At $27 \mathrm{DAT}$, root system fresh and dry weights were different between the plants treated with $0 \%$ or $3 \% \mathrm{H}_{2} \mathrm{O}_{2}$ and the plants treated with $6 \%$ or $12 \% \mathrm{H}_{2} \mathrm{O}_{2}$ (Table 3 ). This result was reflected across all root data criteria, with the control plants and plants treated with $3 \%$ $\mathrm{H}_{2} \mathrm{O}_{2}$ different from those treated with $6 \%$ or $12 \% \mathrm{H}_{2} \mathrm{O}_{2}$ (Table 3 ). Although $3 \% \quad \mathrm{H}_{2} \mathrm{O}_{2}$ resulted in minor symptoms of root discoloration, wrinkling, and decay, viable roots were still present when final data were collected. Root viability was ascertained by observing visible root damage, moisture uptake capability, final fresh and dry root weights, and presence of root initials. Not only did the $3 \% \mathrm{H}_{2} \mathrm{O}_{2}$ treatment result in less visible root damage than the $6 \%$ or $12 \%$ treatments (Table 3 ), but also the substrate of the 3\%-treated plants dried down alongside the $0 \%$ control plants

Table 1. Root health rating scale used to characterize 'Vivaldi' hybrid phalaenopsis orchid root health after treatment with hydrogen peroxide.

\begin{tabular}{|c|c|}
\hline Rating & Root characteristics \\
\hline 5 & $\begin{array}{l}\text { Roots are healthy with no degradation. Roots are vibrant green to silver-green and have a firm } \\
\text { texture (Fig. 5A). Roots are taking in moisture actively (medium dries between watering). }\end{array}$ \\
\hline 4 & $\begin{array}{l}\text { Symptoms of dehydration are showing in lower roots. Wrinkling is visible lengthwise along the } \\
\text { root, yet roots maintain their green color (Fig. } 4 \mathrm{~A} \text { ). Medium continues to dry between } \\
\text { watering. }\end{array}$ \\
\hline 3 & $\begin{array}{l}\text { Expanded dehydration symptoms are visible toward the upper portion of the root zone (Fig. } \\
\text { 4A). Inefficient moisture uptake causes moist media with little to no dry-down between } \\
\text { watering. Salts are visible on the root surface (Fig. } 4 \mathrm{~B} \text { ). }\end{array}$ \\
\hline 2 & $\begin{array}{l}\text { Moisture uptake is almost completely halted. Patches of orange, brown, and black show } \\
\text { throughout the root zone. Roots are mostly rotten and are soft in texture (Fig. 4D). }\end{array}$ \\
\hline 1 & The majority of the root mass is degraded, black, and rotten (Fig. $5 \mathrm{C}$ ). \\
\hline
\end{tabular}




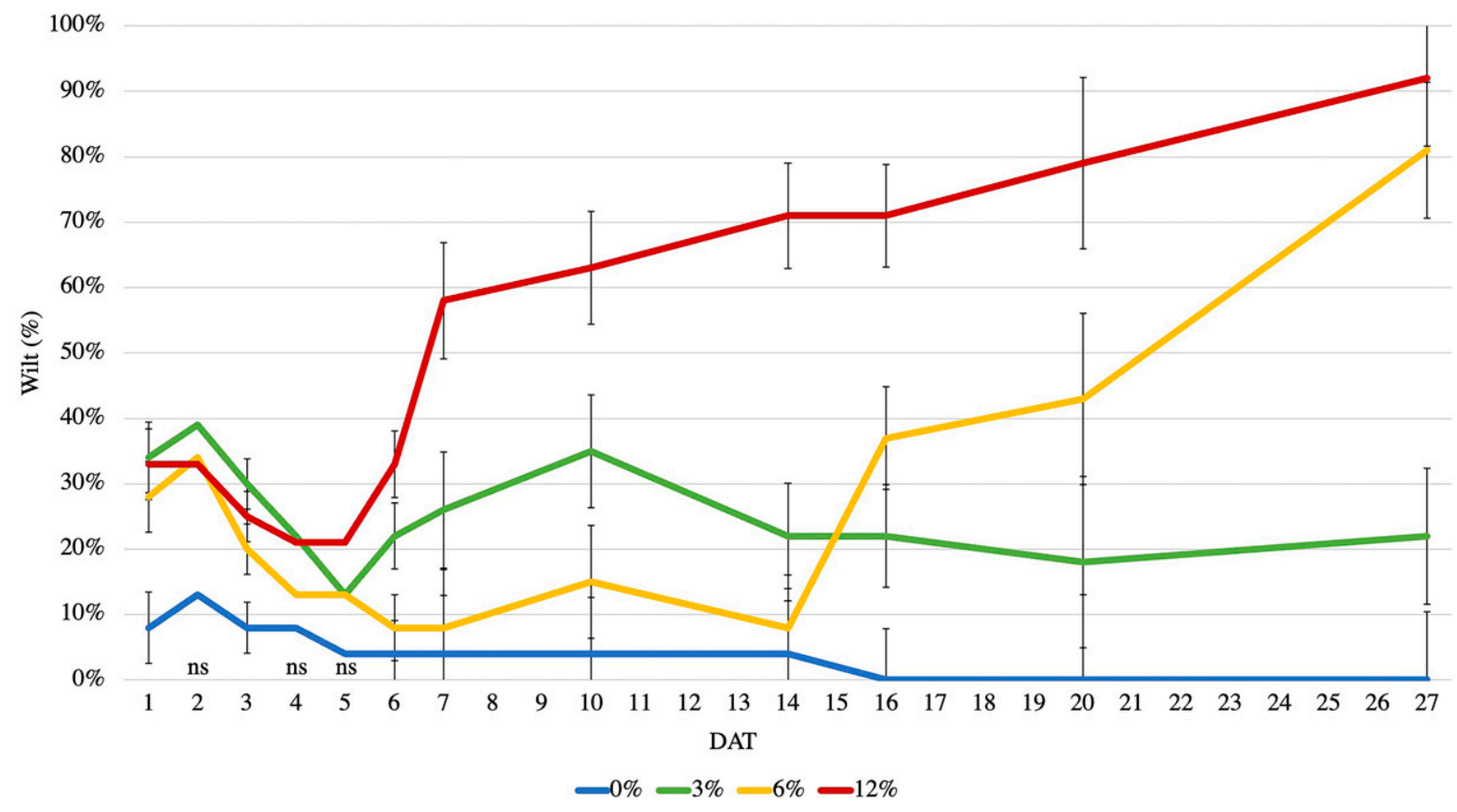

Fig. 2. Percentage of foliage wilt of 'Vivaldi' hybrid phalaenopsis orchid from 1 to $27 \mathrm{~d}$ after treatment (DAT) with hydrogen peroxide $(n=4)$. se bars for by-date analysis are shown around each mean. ns, not significant.

between irrigations. In contrast, plants treated with $6 \%$ or $12 \% \mathrm{H}_{2} \mathrm{O}_{2}$ failed to dry periodically between irrigation and remained continually moist. Although fewer in number than in the control plants, new root initials were also present in the root systems of plants treated with $3 \%$ $\mathrm{H}_{2} \mathrm{O}_{2}$ at 10 DAT (Table 3).

The roots of the plants treated with $6 \%$ or $12 \% \mathrm{H}_{2} \mathrm{O}_{2}$ were damaged beyond recovery, causing severe health decline of the entire plant (Table 3, Figs. 3, 5, and $6)$. The two higher $\mathrm{H}_{2} \mathrm{O}_{2}$ concentrations damaged roots to the point that they no longer absorbed water. With litthe to no water absorption, roots remained consistently moist, leading to eventual decay. A clear difference between healthy and rotten orchid roots could be seen in the root cross sections taken on 7 DAT (Fig. 5B and D), which showed differences in cellular viability of cortex and absorptive complex (velamen and exodermis) tissues. Although damage to these areas of the roots was extensive, damage had not yet reached the endodermis and conductive tissue in rotten root cross sections (data not shown). And although the conductive tissue remained intact in degraded roots, because these roots were not capable of water or mineral uptake or storage, they failed to support the affected plants.

Because orchids are produced in clear containers, it is common for algae to develop in root zones. Although not a primary objective of our research, a change in algae health was observed across treatments. It is important to note that although algae were subdued significantly by using a single $6 \%$ or $12 \%$ $\mathrm{H}_{2} \mathrm{O}_{2}$ root dip to treat the root zone
(Table 3, Fig. 7), algae were not subdued in the root zone by using a $3 \%$ $\mathrm{H}_{2} \mathrm{O}_{2}$ treatment (Table 3),

FOLIAGE DAMAgE. After root damage, foliage decline ensued as a result of root failure in the plants treated with $6 \%$ or $12 \% \mathrm{H}_{2} \mathrm{O}_{2}$ (Table 3, Figs. 2, 3, and 6). Symptoms appeared as lower leaf yellowing and foliage wilt (Figs. 4E and 6). Foliage symptoms and health decline were not noticeable for at least 3 weeks after application in the $3 \%$ or $6 \% \mathrm{H}_{2} \mathrm{O}_{2}$ treatments, although foliage health declined for the $12 \% \mathrm{H}_{2} \mathrm{O}_{2}$ beginning 7 DAT (Figs. 2 and 3). Although foliage dry weight was not statistically different 27 DAT, the differences observed in percent foliage wilt and foliage fresh weight suggest that dry weight may have differed among treatments if the study had continued for a longer period (Table 3).

Table 2. Foliage health rating scale used to characterize 'Vivaldi' hybrid phalaenopsis orchid foliage health after treatment with hydrogen peroxide.

\begin{tabular}{cl}
\hline Rating & Foliage characteristics \\
\hline 5 & Turgid, green leaves with minimal lower leaf discoloration (Fig. 6A). \\
4 & Mostly turgid, green leaves. Lowest one to two leaves soft (15\% to 20\%). \\
3 & Foliage beginning to display leathery texture and/or yellowing lower leaves (Fig. 4E). \\
2 & Lowest three to four leaves soft (30\% to 60\%). \\
1 & Most leaves are soft and leathery (60\% to 90\%). Lowest leaves yellowing (Fig. 4E). \\
\hline
\end{tabular}




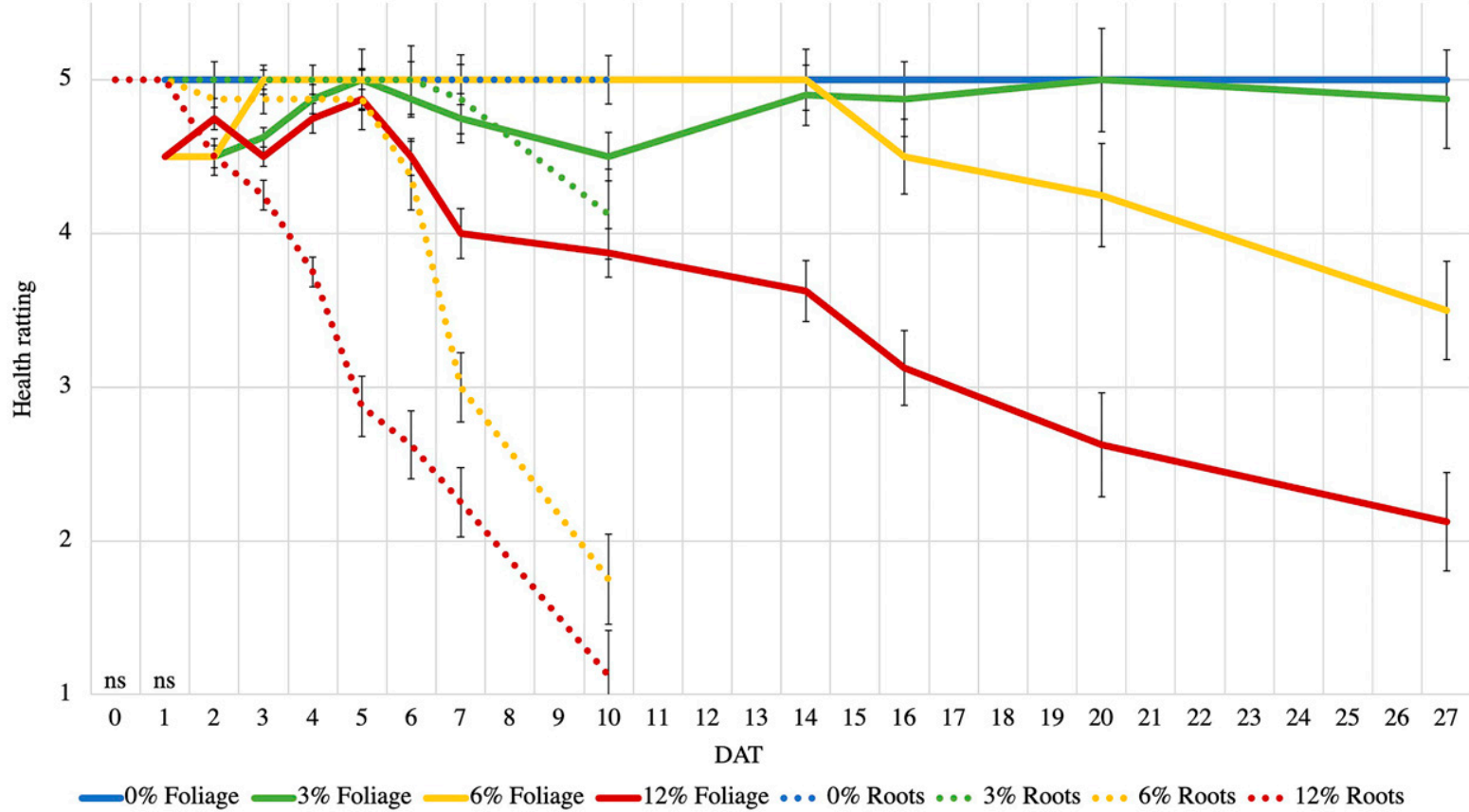

Fig. 3. 'Vivaldi' hybrid phalaenopsis orchid root health ratings [5-point scale (Table 1)] of four hydrogen peroxide rates from 1 to $10 \mathrm{~d}$ after treatment (DAT) and foliage health ratings [5-point scale (Table 2)] from 1 to 27 DAT (n = 4). sE bars for by-date analysis are shown around each mean for each data type: root or foliage health rating. ns, not significant.
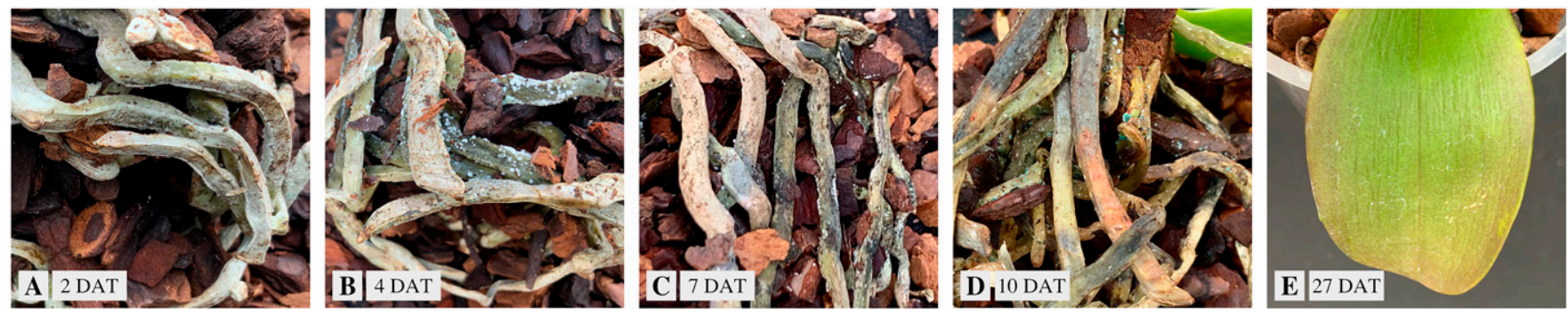

Fig. 4. Phytotoxicity symptoms observed on 'Vivaldi' hybrid phalaenopsis orchid after a single subirrigation root dip of hydrogen peroxide included (A) wrinkled, dehydrated roots; (B) salt excretion on root surfaces; (C) algae death; (D) orange, brown, and black discoloration, and eventual decay; and (E) foliage wilt and yellowing (E). Days after treatment (DAT) are indicated.

Table 3. Final data on 'Vivaldi' hybrid phalaenopsis orchid $10 \mathrm{~d}$ after treatment [DAT (roots)] and 27 DAT (foliage, flowers, fresh and dry weights) with dips in hydrogen peroxide $\left(\mathrm{H}_{2} \mathrm{O}_{2}\right)$.

\begin{tabular}{|c|c|c|c|c|c|c|c|c|c|c|c|}
\hline $\begin{array}{l}\mathrm{H}_{2} \mathrm{O}_{2} \\
\text { rate (\%) }\end{array}$ & $\begin{array}{l}\text { Root health } \\
\text { rating }(1-5 \text { scale })^{\mathrm{z}}\end{array}$ & $\begin{array}{l}\text { Visible root } \\
\text { damage (\%) }\end{array}$ & $\begin{array}{l}\text { Root fresh } \\
\text { wt }(g)^{y}\end{array}$ & $\begin{array}{l}\text { Root dry } \\
\text { wt (g) }\end{array}$ & $\begin{array}{c}\text { Foliage health } \\
\text { rating }(1-5 \text { scale })^{z}\end{array}$ & $\begin{array}{c}\text { Visible foliar } \\
\text { damage (\%) }\end{array}$ & $\begin{array}{c}\text { Foliage wilt } \\
(\%)\end{array}$ & $\begin{array}{c}\text { Foliage fresh } \\
\text { wt (g) }\end{array}$ & $\begin{array}{c}\text { Foliage dry } \\
\text { wt (g) }\end{array}$ & $\begin{array}{c}\text { Algae } \\
\text { control }^{\mathrm{x}}\end{array}$ & $\begin{array}{c}\text { Root initials } \\
\text { present }^{\mathbf{w}}\end{array}$ \\
\hline 0 & $5.00 \mathrm{a}^{\mathrm{v}}$ & $0.0 \mathrm{a}$ & $77 \mathrm{a}$ & $6.22 \mathrm{a}$ & $5.00 \mathrm{a}$ & $0.0 \mathrm{a}$ & $0.0 \mathrm{a}$ & $132 \mathrm{a}$ & $8.60 \mathrm{a}$ & No & Yes \\
\hline 3 & $4.13 \mathrm{a}$ & $7.0 \mathrm{a}$ & $68 \mathrm{a}$ & $5.72 \mathrm{a}$ & $4.88 \mathrm{a}$ & $0.0 \mathrm{a}$ & $21.7 \mathrm{a}$ & $121 \mathrm{ab}$ & $7.97 \mathrm{a}$ & No & Yes \\
\hline 6 & $1.75 \mathrm{~b}$ & $66.3 \mathrm{~b}$ & $47 \mathrm{~b}$ & $5.04 \mathrm{ab}$ & $3.50 \mathrm{~b}$ & $27.5 \mathrm{ab}$ & $81.3 \mathrm{~b}$ & $93 \mathrm{bc}$ & $6.98 \mathrm{a}$ & Yes & No \\
\hline 12 & $1.13 \mathrm{~b}$ & $83.8 \mathrm{~b}$ & $35 \mathrm{~b}$ & $4.14 \mathrm{~b}$ & $2.13 \mathrm{c}$ & $62.5 \mathrm{~b}$ & $91.7 \mathrm{~b}$ & $86 \mathrm{c}$ & $7.13 \mathrm{a}$ & Yes & No \\
\hline
\end{tabular}

${ }^{\mathrm{z}} 5=$ healthy and $\mathrm{l}=$ severe damage, as described in Table $\mathrm{l}$ (root health rating) or Table 2 (foliage health rating).

${ }^{\mathrm{y}} 1 \mathrm{~g}=0.0353 \mathrm{oz}$.

${ }^{x} Y e s=$ algae was controlled in the substrate; $\mathrm{No}=$ algae was still visibly present after treatment with $\mathrm{H}_{2} \mathrm{O}_{2}$.

${ }^{\text {w }}$ Yes $=$ root initials were present after 10 DAT with $\mathrm{H}_{2} \mathrm{O}_{2} ; \mathrm{No}=$ root initials were not present after $10 \mathrm{DAT}$ with $\mathrm{H}_{2} \mathrm{O}_{2}$

${ }^{v}$ Means were compared using Tukey's honestly significant difference test at a probability level of 0.05.

Flower DAMAge. Although root and foliage health worsened as $\mathrm{H}_{2} \mathrm{O}_{2}$ concentration increased, a significant effect on flowers was not seen during the duration of the trial [Table 3, Fig. 3 (flower data not shown)]. Although flowers aged over all treatments, there was no difference among treatments in flower/bud abscission.

\section{Discussion}

Using a single $\mathrm{H}_{2} \mathrm{O}_{2}$ root dip at any concentration greater than $3 \%$ causes phytotoxic symptoms in phalaenopsis 

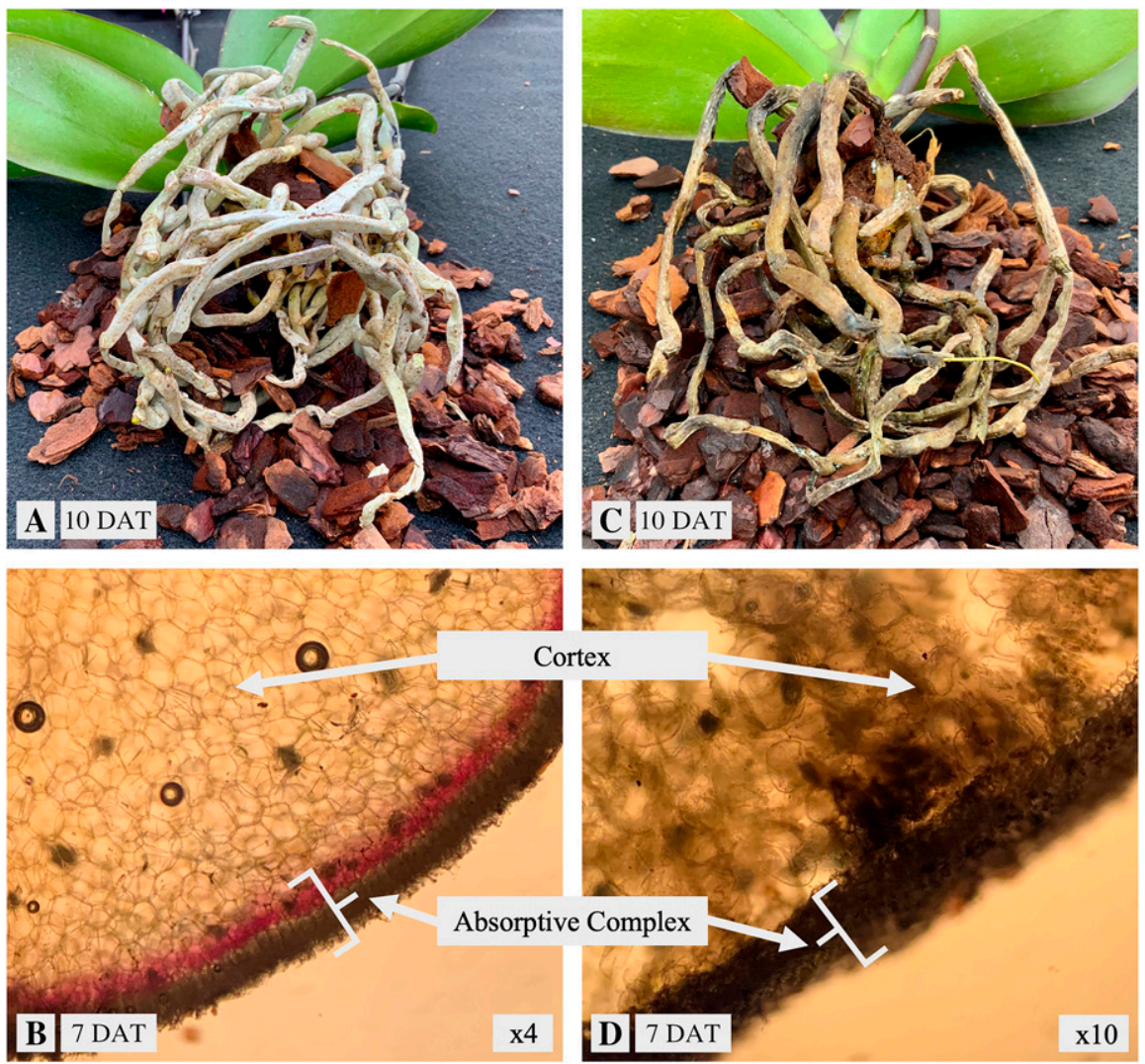

Fig. 5. Macro- and microscopic comparisons of the roots of (A, B) a 'Vivaldi' hybrid phalaenopsis orchid not treated with hydrogen peroxide and $(C, D)$ a 'Vivaldi' hybrid phalaenopsis orchid treated with $12 \%$ hydrogen peroxide, respectively. Days after treatment (DAT) are indicated.

that are detrimental to plant health. Complete root decay and plant failure was caused by $6 \%$ or $12 \% \mathrm{H}_{2} \mathrm{O}_{2}$ root dips, which caused a problem equal to what consumers desire to treat and/or prevent. Although plants treated with $3 \% \mathrm{H}_{2} \mathrm{O}_{2}$ showed the potential to rebound from the phytotoxic effects caused by a single $\mathrm{H}_{2} \mathrm{O}_{2}$ root dip, the long-term effects are unknown.

Like many bacteria and fungal-like organisms, algae are protist microorganisms with chloroplasts that thrive in environments with light, water, and nutrients, including hydroponic systems and the root zones of orchids produced in clear containers. As such, algae are a visible indicator of microorganism viability in plant root systems. Because the main intent of treating orchid roots with $\mathrm{H}_{2} \mathrm{O}_{2}$ is to decrease the pathogenic microorganism population in the root zone, it is reasonable to use algae as an indicator of treatment efficacy. Although using $3 \% \mathrm{H}_{2} \mathrm{O}_{2}$ as a single root dip was found to be a relatively safe threshold for phalaenopsis orchids, because algae were not killed completely at this concentration, the potential efficacy of using $3 \% \mathrm{H}_{2} \mathrm{O}_{2}$ to treat pathogenic microorganisms in the root zone should be questioned. As such, $\mathrm{H}_{2} \mathrm{O}_{2}$ root dips at rates that would effectively eliminate algae or pathogens have the potential to cause root failure rather than abate root decay. An $\mathrm{H}_{2} \mathrm{O}_{2}$ root dip at a rate of $3 \%$ caused limited root health decline, potentially setting back plant health rather than improving it (Table 3, Fig. 3), although cumulative damage is possible with repeated applications. Also of note is that some microorganisms beneficial to plant health would potentially die during a $\mathrm{H}_{2} \mathrm{O}_{2}$ root dip treatment.

We hypothesize that because $\mathrm{H}_{2} \mathrm{O}_{2}$ is an ROS, it harmed the cellular structure of the roots' absorptive complex. According to Bercu et al. (2011), the exodermis and velamen of Phalaenopsis amabilis roots function jointly as an absorptive complex, taking in moisture and mineral nutrients. Benzing et al. (1982) referred to the velamen in orchids as "rechargeable dead space" capable of taking in moisture and mineral nutrients in seconds. Because the velamen is capable of "charging" rapidly with moisture and the minerals in solution, it is likely that when the orchid roots were dipped in $\mathrm{H}_{2} \mathrm{O}_{2}$, it was absorbed by the velamen, holding a high concentration of an ROS near the exodermis, where it reacted further.

After the dip in $\mathrm{H}_{2} \mathrm{O}_{2}$, extensive root decay ensued in the plants treated with $6 \%$ or $12 \% \quad \mathrm{H}_{2} \mathrm{O}_{2}$. Because a large percentage of the root absorptive complex was damaged, it was not possible for the roots to absorb moisture (Fig. $5 \mathrm{D}$ ). The roots first became dehydrated (Fig. 4A). Afterward, as the cortex began to degrade, salts were excreted from the roots onto the surface of the velamen (Fig. 4B). Because plants were only fertilized once, 3 weeks before the study began, and were then irrigated several times until 0 DAT, we believe that the source of the accumulated salts was endogenous rather than exogenous. Further evaluation is needed to solidify the reason for cellular malfunction caused by $\mathrm{H}_{2} \mathrm{O}_{2}$ and the source of salt excretion.

Because symptoms of phytotoxicity did not manifest above the root zone for 3 weeks after treatment, it would be difficult for a consumer to discern whether an $\mathrm{H}_{2} \mathrm{O}_{2}$ root dip failed to remedy the problem or caused the problem. In fact, root decay that occurs several months after plant purchase is not likely caused by a fungal pathogen, but instead by consumer watering practices. In sum, it is better to advise home growers to remedy root decay via environmental and care changes, such as adjusting irrigation methods or repotting into fresh, well-drained substrate, than by applying a home remedy of any kind.

\section{Conclusion}

Based on our results, $3 \%$ is the maximum $\mathrm{H}_{2} \mathrm{O}_{2}$ concentration that should be considered for application to phalaenopsis orchids as a single root dip to avoid causing complete root failure. Although $3 \% \mathrm{H}_{2} \mathrm{O}_{2}$ did not result in severe symptoms of phytotoxicity, long-term plant health effects are unknown, and a long-term study is warranted to delineate these effects. The larger issue is that the mode of 

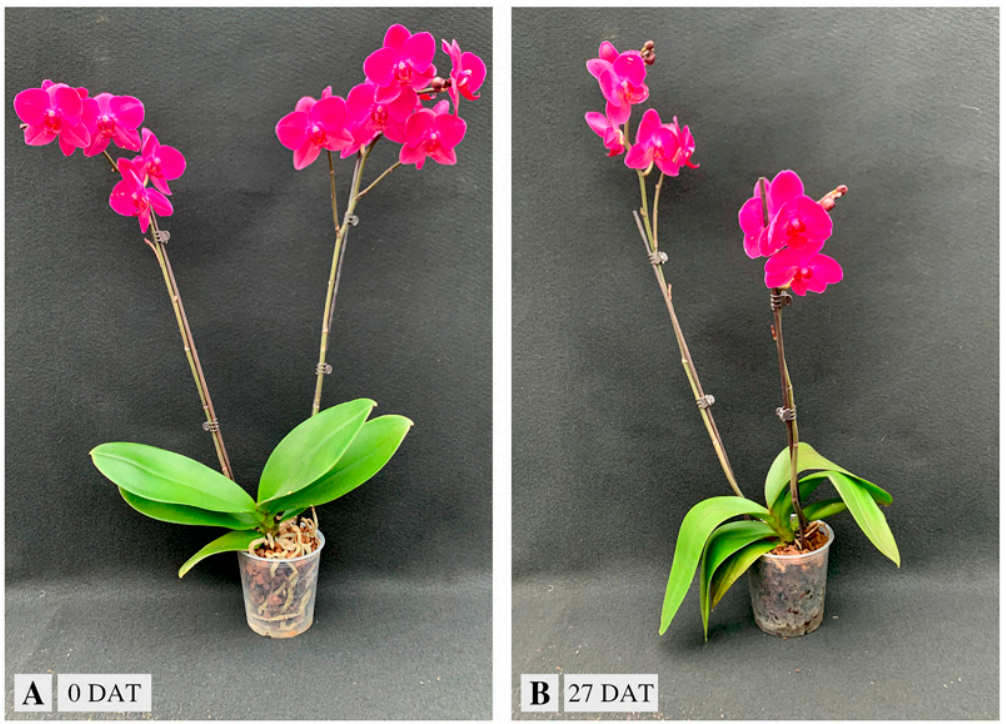

Fig. 6. Comparison of the same 'Vivaldi' hybrid phalaenopsis orchid treated with (A) a $12 \%$ hydrogen peroxide root dip on $0 \mathrm{~d}$ after treatment (DAT) and (B) 27 DAT.
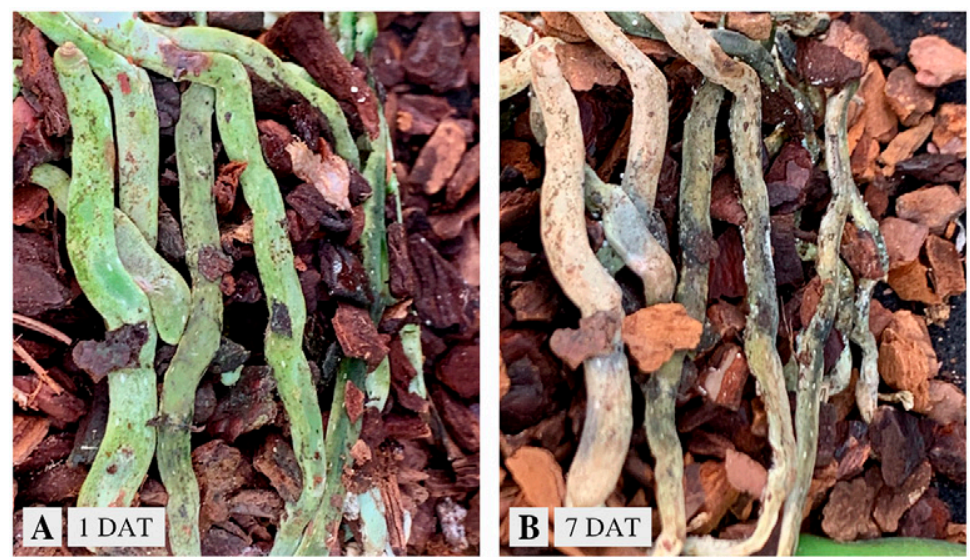

Fig. 7. Comparison of algae health in the same 'Vivaldi' hybrid phalaenopsis orchid treated with (A) a $12 \%$ hydrogen peroxide root dip on $1 \mathrm{~d}$ after treatment (DAT) and (B) 7 DAT.

action of $\mathrm{H}_{2} \mathrm{O}_{2}$ as a surface disinfectant is not well matched with the anatomy of epiphytic orchid roots. Root decay is likely associated with consumer care as opposed to root rot pathogens. For these reasons, we do not believe that $\mathrm{H}_{2} \mathrm{O}_{2}$ should be recommended as a home remedy for root decay on phalaenopsis orchids.

\section{Literature cited}

Ali, A.A.M. 2018. Role of hydrogen peroxide in management of root rot and wilt disease of thyme plant. J. Phytopathol. Pest Mgt. 5:1-13, https://doi.org/10.1111/ j.1365-2672.1983.tb02637.x.

Baldry, M.G.C. 1983. The bactericidal, fungicidal and sporicidal properties of hydrogen peroxide and peracetic acid. J. Appl. Bacteriol. 54:417-423, https://doi. org/10.1111/j.1365-2672.1983.tb02637.x.

Benzing, D.H., D.W. Ott, and W.E. Friedman. 1982. Roots of Sobralia macrantha (Orchidaceae): Structure and function of the velamen-exodermis complex. Amer. J. Bot. 69:608-614, https:// doi.org/10.2307/2443070.

Bercu, R., A. Bavaru, and L. Broasc. 2011. Anatomical aspects of Phalaenopsis amabilis (L.). Blume. Ann. Rom. Soc. Cell Biol. 16:102-109.

Bottom, S. 2012. Watering orchids during each season. St. Augustine Orchid Soc. Newsletter 7(9):10-11.

Bottom, S. 2017. Hydrogen peroxide. St. Augustine Orchid Soc. Nwsl. 12(7):10-11.

Eicher-Sodo, M., R. Gordon, and Y. Zheng. 2019. Characterizing the phytotoxic effects of hydrogen peroxide on common microgreen species and lettuce cultivars. HortTechnology 29:283-289, https://doi.org/ 10.21273/HORTTECH04255-18.

Krumova, K. and G. Cosa. 2016. Overview of reactive oxygen species, p. 1-21. In: S. Nonell and C. Flors (eds.). Singlet oxygen: Applications in biosciences and nanosciences. Royal Society of Chemistry, Cambridge, UK, https://doi.org/ 10.1039/9781782622208-00001.

Miss Orchid Girl. 2014. Q\&A: How to clean orchid roots? 27 July 2021. <https:// www.youtube.com/watch?v= hvufuQD4Gu4>.

My First Orchid. 2016. Orchid health: Rot. 27 July 2021. < https://myfirstorchid.com/ 2016/08/12/root-rot/>.

Orchid Friends. 2020. How to save an orchid. 27 July 2021. <https://orchidfriends.com/ how-to-save-an-orchid/ $>$.

Raudales, R.E., J.L. Parke, C.L. Guy, and P.R. Fisher. 2014. Control of waterborne microbes in irrigation: A review. Agr. Water Mgt. 143:9-28, https://doi.org/10.1016/ j.agwat.2014.06.007.

Webber, C.L., III, C.L. Webber, Jr., and S.J. Sandtner. 2009. Impact of hydrogen peroxide as a soil amendment on nasturtiums. J. Env. Monitoring Restoration 6:110-113. 